\title{
The Impact of Migration on a Regulated Rental Market
}

\author{
Adam Alexander Tyrcha ${ }^{1}$ \\ ${ }^{1}$ University of Cambridge, Cambridge, United Kingdom \\ Received: 21 June 2019/Accepted: 3 February 2020
}

\begin{abstract}
Throughout the 20th century, the Swedish rental market has generally been heavily regulated, with both a rental queue in place, as well as fixed rents, with a limited ability to vary these. Though these systems remain in place, in the 21st century, a number of deregulatory measures have been taken. Meanwhile, evolving migration flows and strong humanitarian migration in particular have continued. These developments combined mean that now more than ever, the impacts of migration on the rental housing market are increasingly likely. This paper investigates the relationship between foreign-born and internal migration and rents on the housing market. Findings suggest that foreign-born migration, and refugees in particular, impact rents, especially in major cities.
\end{abstract}

JEL classification: J61, R23, R31, R11

Key words: immigration; internal migration; housing; rents; rental market

\section{Introduction}

Rental markets constitute a crucial segment of most housing markets worldwide due to the flexibility that this type of housing provides, allowing people who lack the means or desire to purchase housing an easily accessible alternative. When considering the rental market, drawing on examples from Sweden are particularly interesting, owing to the differences in the country's rental system when compared to most other systems. Though public and private actors construct rental housing, the Swedish rental system is rent controlled, with the ability of the landlord to set rent being limited. However, some deregulation has occurred over the past decade or so, transforming the nature of this market (Section 2).

Meanwhile, migration flows coming into Sweden also continue to transform. In 2017, 144,489 people migrated to Sweden, where $27 \%$ of all new residence permits approved were granted to humanitarian migrants, with $35 \%$ corresponding to labour migrants, and $24 \%$ to family reunification migrants (SCB 2017). Hence, it is clear that a diverse range of migrants continue to seek opportunities for themselves in Sweden.

Substantial amounts of research have been conducted into the relationship between migration and the owner-occupied housing market (Saiz 2007, Degen, Fischer 2009, Gonzalez, Ortega 2012, Tyrcha, Abreu 2019). Some research has also been conducted into the relationship between migration and the rental market, generally finding a $1 \%$ increase in population leads to between 0-1\% increase in rents (Ottaviano, Peri 2005, Saiz 2007, Latif 2015, Tumen 2016, Mussa et al. 2017). This is an important relationship 
to understand, owing to the large proportion of the global population that does live in rented accommodation. Both migrants and natives alike, particularly those who are less affluent, tend to be overly reliant on rental accommodation (World Bank 2019), meaning that the global relevance of this topic is clear.

However, no research has been conducted in Sweden, despite 59 per cent of apartments in Sweden being rental apartments (SCB 2018). Furthermore, the unique institutional context of the Swedish market, where rents have historically been highly regulated, but underwent somewhat substantial deregulation in 2011 (SABO 2011), provides an interesting context for the analysis of the impact of migration on a recently deregulated housing market. Thus, in this paper I extend the literature by investigating the impacts of migration on rent in the highly regulated Swedish context. The paper will examine both general and regional impacts, while accounting for internal migration as well as different forms of foreign-born migration, allowing for further extension of the literature in this manner.

\section{Background}

\subsection{Literature Review}

As alluded to in Section 1, there has been some research going into the impacts of migration on the rental market previously, though primarily in unregulated markets. This research has found that migration has an impact on rents, owing primarily to the demand-driven effects that an influx of population creates, pushing up prices by $0-1 \%$ (Ottaviano, Peri 2005, Saiz 2007, Latif 2015, Tumen 2016, Mussa et al. 2017). Indeed, perhaps the seminal study on the impact of immigration on the rental market is Saiz (2003). He finds that following an exogenous migration shock to Miami's renter population in the 1970 s and 1980 , rents rose by " $8 \%$ to $11 \%$ more in Miami than in comparison groups between 1979 and 1981." Saiz finds that the shock to unskilled migration had a greater impact on rents in poor areas and persisted in the years following the migration shock. His study extended to the fairly unique migration boost provided to Miami by the Mariel Boatlift from Cuba, and thus it is possible that impacts were different from more gradual migration impacts.

However, the trends found by Saiz (2003) also hold in Saiz's own follow-up (Saiz 2007 ), where he finds that immigration inflows equal to $1 \%$ of a city's size lead to a $0.6 \%$ increase in rents, confirming this on the national scale. Mussa et al. (2017), though, use US data to find an impact of $0.8 \%$ in the immediate area, rising to $1.6 \%$ in surrounding MSAs indicating the presence of spillover effects expected where there is spatial sorting. A recent study by Tumen (2016) in Turkey confirms the above findings, and although a different methodology is employed, finds a $5.5 \%$ increase in house rents overall resulting from the natural experiment of Syrian refugees coming to Turkey. Results here could be significantly stronger owing to the substantially varying nature of the migration flow, as well as the slightly less developed nature of the receiving country. The same reasoning could be applied to an even more recent study, though of a relatively more dated time period in the fall of the Berlin Wall. This study also finds that an increase in migration corresponding to $1 \%$ of western Berlin's population resulted in rents rising between 3.3-4.8\% (Kürschner 2017).

Nevertheless, impacts are not uniformly positive across all studies. "An inflow of immigrants equal to 1 percent of the initial population is associated with a $0.14-0.18$ percent increase in average housing rent" (Aitken 2014, p. 13) in England and Wales, indicating that a moderate effect remains a possibility in this regard. Differences found in this study could also broadly be a result of the generally unique nature of the UK migration and housing context. However, similar findings are made by Latif (2015) in Canada, where an increase in migration of $1 \%$ is found to correspond to a $0.14-0.17 \%$ increase in rents, although a lack of key controlled variables could serve to explain this. Indeed, this corresponds well with the findings of Sharpe (2015), who after introducing a range of new control variables, is unable to ascertain any causal effects of migration on the US rental market. This is important to keep in mind when conducting analysis, and underlines that diverging impacts could be found depending on controlled variables, 


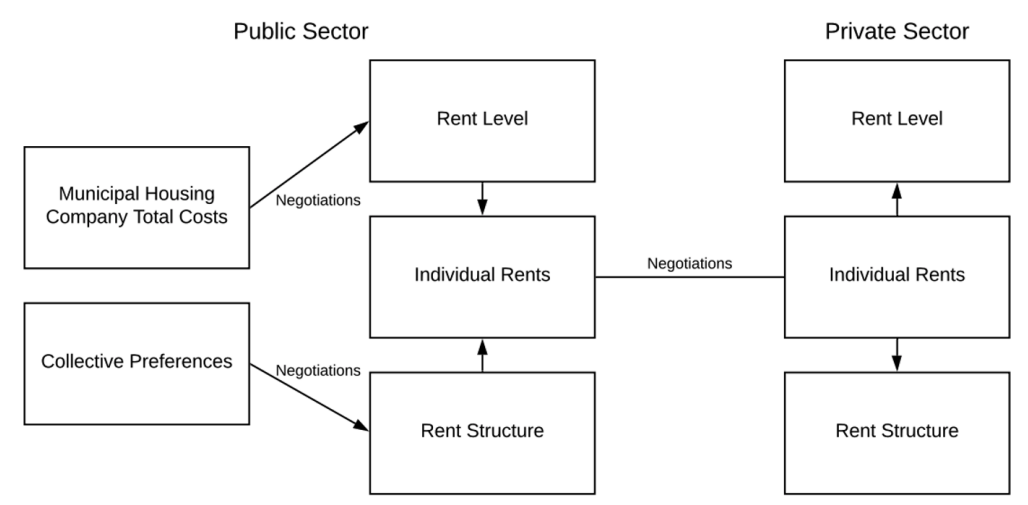

Source: Adapted from: Bengtsson 1994.

Figure 1: The Swedish use-value system

techniques taken, and countries chosen to study. This is particularly relevant in Sweden, where the rental market operates under a fairly unique rental system, described in the following section (Section 2.2).

\subsection{The Swedish Rental Market}

The rental system in Sweden has its groundings in the Rent Regulation Act of 1942 and the Rental Act of 1968. In essence, the aim of the law is: "First, regardless of the market situation, the landlord should be prevented from raising the rent of a flat in order to get rid of an undesired sitting tenant. Second, in times of housing shortage, the landlord should be prevented from raising the rent to market level the sitting tenant cannot afford. Third, the landlord should be prevented from raising the rent without the sitting tenant having a real chance to look after his interests, individually or with the assistance of a tenants association." Nevertheless, the rent should, in theory, still "reflect market rents on a market in long-run equilibrium, regardless of whether the market at any given time is actually in equilibrium or not" (Bengtsson 1994, p. 3).

Though the current outcome was not necessarily the intent upon creation, Figure 1 demonstrates the state of the rental system in practice, until the deregulatory reform in 2011.

The original intention of the system was for the public and private sectors to have input in negotiations (Bengtsson 1994). However, as Figure 1 indicates, the private sector had effectively become a price-taker in the equation, with "tenant associations [having] the formal right to collective negotiations, even against the landlord's will" (Bengtsson 1994, p. 4), effectively removing bargaining from the process. Instead, "claimed rents [were] compared with the local rent level of dwellings judged to have the same use-value in terms of size, standard, service, location and more" (Lind 2001, p. 11), where "reasonableness of a rent in the private sector is directly related to the rent set by the public sector" (Lind 2001, p. 11). Further, newer apartments tend to have higher rents, owing to a lack of regular rent reviews in older apartments, and not accounting for various factors in the rent-setting process e.g. the role of refurbishment. Indeed, urban renewal and re-urbanization has resulted in "the gap between the actual rent and the market rent increasing dramatically in old stock in attractive areas" (Lind 2001, p. 3).

Though some of the above still holds, 2011 saw a wide-reaching reform, enabling a higher degree of negotiation and competitiveness in the rent-setting process, while still maintaining elements of rent regulation. Since the 1st of January 2011, the municipal housing companies' role has been vastly diminished, and they are no longer primarily involved in rental negotiations, as shown in Figure 1. Instead, rents can be negotiated with any relevant party (SABO 2011). This means that there is scope for the private sector to not just be a price-taker, but be more actively involved and even leading in the negotiations. Though rents must still be tested against the use-value of comparable properties, enabling the private sector to negotiate has resulted in the process taking on 
more free market characteristics. Partly as a result of this, as well as a form of "free market creep" resulting from other minor reforms enacted throughout much of the 21st century, rents rose by $19 \%$ between 2008-2018, a markedly higher increase than previous decades - which can be compared to $9 \% \mathrm{CPI}$ inflation over the same time period (SCB 2018). Hence, migration having an impact on rents is a highly feasible relationship(?). In 2019, a government proposal which would enable rents to be set completely freely among newly produced housing was introduced and is currently undergoing investigation. This could substantially transform the housing market in the long-term.

Additional complexities arise owing to the rental queue system in Sweden, where rental properties are not advertised on the free market. Instead, a queuing mechanism exists, with properties allocated to people in the queue as they become available. Nevertheless, internal and international migration have been shown to impact this rental queue (Tyrcha 2019), and thus, it is feasible that migration could impact rental levels, too. Sweden is a particularly interesting case to study, owing to the widely unexplored, regulated or semi-regulated nature of the rental market. The aforementioned deregulatory reform means that the impacts of migration on the rental market could now feasibly be stronger than in past decades - though, indeed, even the previously more regulated nature of the market does not necessarily preclude migration's impact on rents.

The mechanism by which migrants create an impact on rents is by and large the same as in an unregulated rental market. An inflow of migrants causes upward pressure on rents, given constant supply and ceteris paribus, as demand for rental housing exceeds supply of rental housing. Under the new 2011 regulations, this mechanism is allowed to function in a more unimpeded way than previously, as rental housing owners are more able to adjust rents upon rental review than previously (though remain subject to certain use value restrictions which limit the permissible annual growth rate of rents, as well as the absolute value of rents, relative to other comparable properties). However, even under the regulated system, public sector owners would often feel forced to adjust rents a little more than the average in a given location, depending on demand, owing to outward pressures placed on them from governments or other public and private actors. Reasons for this could include the desire to combat the parallel black market, or limit the size of the rental queue by increasing turnover of apartments (Bengtsson 1994, Lind 2001, SCB 2019). Such impacts could, both before and after the reform, manifest partly owing to the aforementioned ability of certain migrant groups to bypass the rental queue and thus indirectly impact the rental market. The impact of such heterogeneities, and the subsequent differences in impact of different migrant groups, are discussed further in Section 2.3 below.

Nevertheless, given the unique institutional context, it also must be seen as relatively unlikely that the Swedish rental market will see the same impacts as markets in less stringently regulated contexts. The relationship between migration and rental levels on the unique Swedish rental market will be explored further in this paper.

\subsection{The Role of Heterogeneities}

Meanwhile, it is important to also acknowledge directly that the human capital differences among migrant groups could indirectly serve to influence their motivations to migrate, and thus also their ultimate impact on the housing market. Eichholtz, Lindenthal (2014) find that in the context of domestic migration in England, human capital is a key driver of housing demand. To some degree, it could therefore also be theorized that human capital may be an underlying factor influencing the scale of impact of both internal and foreign-born migration on house prices. This is despite evidence of internal migration constituting an interesting migration flow which differs substantially in nature to foreignborn migration, as well as an abundance of evidence of the impacts of internal migration on the labour market (e.g. Friedberg, Hunt 1995, Borjas 2006, Hammarstedt, Palme 2006, Gerdes, Wadensjö 2010, Kerr, Kerr 2011, Dustmann, Frattini 2014), internal migration is very rarely included or analysed in the housing market context (the only paper that does this comprehensively is Wang et al. (2017), in China). Given the size and variation of internal migration flows, it appears clear that inclusion of this variable, separate to foreign-born migration, in analysis would be advisable. The heterogeneity of the variable 


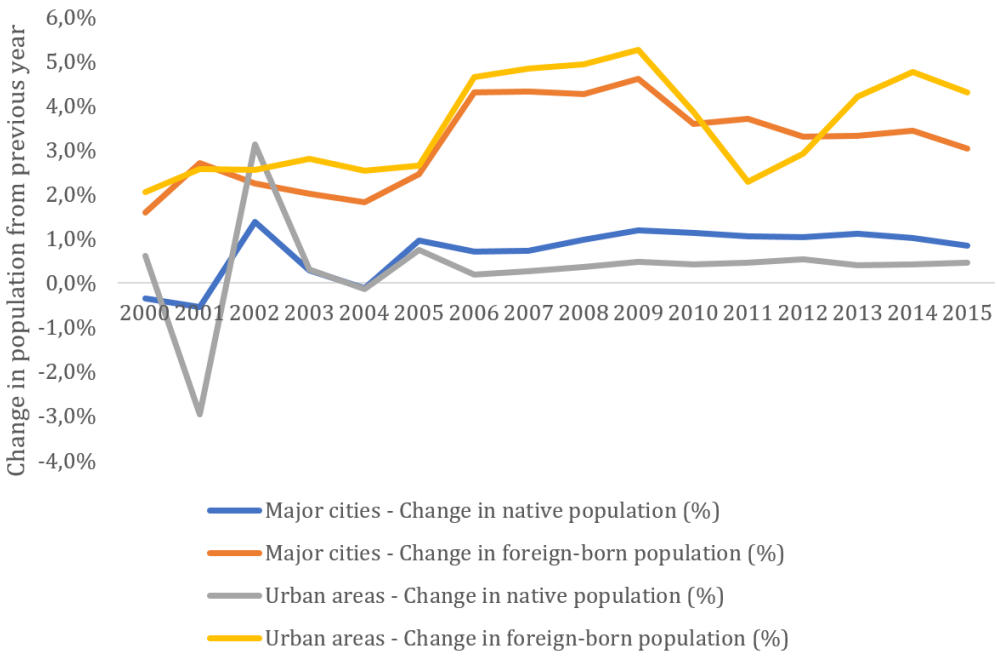

Source of data: SCB, 2018

Figure 2: Change in population in different areas over time

and wide differences when compared to foreign-born migration in the descriptive statistics in Figure 2 mean it is likely that the impacts of internal migration could differ to foreignborn migration. As a result, the two forms of migration will be analysed separately in this paper.

To investigate further along these lines, Figure 2 shows the differences in migration trends between major cities and smaller urban areas, for different kinds of migrants. This is a relevant distinction to make owing to the vastly differing urban characteristics of major cities and smaller urban areas in Sweden. The former consists of three large metropolitan areas (Stockholm, Gothenburg, Malmö), the smallest of which has a population of over 700,000 , while the smaller urban areas in Sweden can have populations as small as 50,000 (SCB 2019). Further, the different types of areas are likely to attract different kinds of migrants, owing to differences in characteristics as a result of the size of regional labour markets, demographical differences, migrant preferences, differences in the nature and likelihood of the presence of certain network effects, and more (SCB 2019).

Figure 2 shows migration trends in Swedish major cities and urban areas over time. It is clear that aside from a few anomalous years in the early 2000s, native people have behaved relatively similarly over time in major cities and urban areas, while foreign-born migrant settlement patterns have varied a little more. Most clear, however, is that the migration flows of natives compared to foreign-born migrants are very different in nature when compared to one another.

Looking more closely at the different dimensions of foreign-born migration also reveals a number of interesting trends. These are shown in Figure 3.

Figure 3 shows the different spikes in foreign-born migration over time since 2000. As can be seen, migration has been rising relatively steadily over the studied period, but with identifiable spikes in different forms of migration in different years. These include a spike in refugee migration around 2006 and from 2012 onwards, as well as spikes in family reunification migration, labour migration, student migration and EU migration in different years.

Among these foreign-born migrant groups, further heterogeneity arises. In the studied period, between 60 to $80 \%$ of refugees (depending on the year) have not been able to obtain their own housing, but have instead been allocated housing by the government (SCB 2018). The government has mandated for all municipalities to provide refugees with housing, with requirements for each municipality depending on a complex set of criteria, including labour market opportunities and housing availability (Wennström, Öner 2015). As a result of this, refugees are unlikely to push up rental levels on their own, but instead will have an indirect impact on rents, as municipalities must find housing for refugees. 


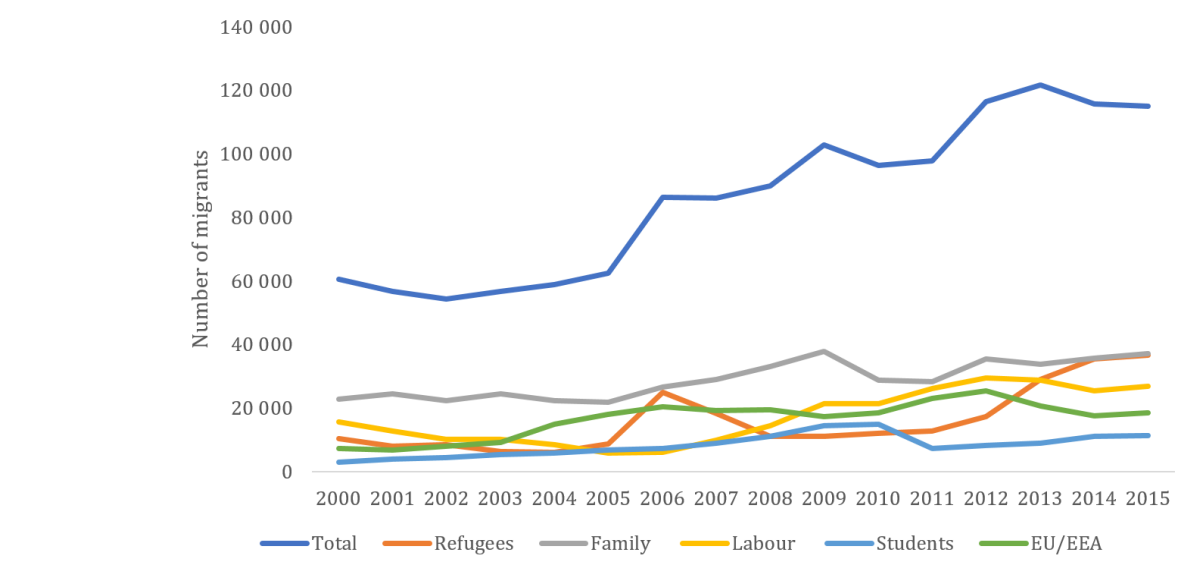

Source of data: Migrationsverket, 2018

Figure 3: Foreign-born migration to Sweden by reason for migration

In this sense, refugees are able to bypass the aforementioned rental queue, and instead indirectly impact the rental market by lowering the supply of rental properties. Despite the lack of a direct impact, and the inability of refugees to spend much on housing, the indirect impact, with migration ultimately impacting rents through an indirect mechanism, is clear.

Meanwhile, family reunification migrants, primarily associated with labour migrant and refugee flows, also present a unique form of migration flow. These forms of migrants are expected to find their own housing, but may have a diminished impact on the rental market as they are inherently less likely to have to attain their own housing, owing to the family links that have allowed them into Sweden. As a result, such migrants may often live at relatively higher densities than other migrants (Migrationsverket 2018), and therefore diminish the impacts that the wider foreign-born group may have on the housing market. Foreign-born labour migrants, meanwhile, are left to their own devices and impact the rental or housing markets in the traditional free market way, as do internal migrants. They may thus also have a stronger impact, owing to their relative willingness and ability to spend, though they are also more able to choose other, more expensive forms of housing. This may in turn limit their impact on relatively more affordable housing types such as rental housing. Hence, it is clear that broadly speaking, the impacts created by foreign-born and internal migrants may differ widely, owing to the wide heterogeneity between and within the two groups. This paper also aims to investigate this.

\section{Data and Methodology}

\subsection{Data Overview and Initial Analysis}

SCB (2018), the Swedish statistical agency, has provided data relating to rents, migrationrelated variables, as well as all controlled variables. The rental data constitutes the mean rent per square meter in January each given year, on the municipal level. The data comes from Sweden's largest, publicly operated statistical agency and thus can be considered reliable. However, this data is only available for a select number of municipalities. Complete data is available for 55 municipalities, and thus, 55 municipalities will be used in the rental analysis.

The model will take the following form: 


$$
\begin{array}{r}
\Delta \ln (r)_{k, t}=\alpha+\theta \frac{\Delta \text { foreign-born }_{k, t}}{\text { population }_{k, t-1}}+\theta \frac{\Delta \text { Swedish-born }_{k, t}}{\text { population }_{k, t-1}}+\beta_{1} \ln \left(\operatorname{In}_{k, t-1}\right)+ \\
\beta_{2} E m_{k, t-1}+\beta_{3} \ln \left(T_{k}\right)+\beta_{4} \ln \left(B_{k}\right)+ \\
\beta_{5} A_{k}+\beta_{6} N S_{k, t-1}+\beta_{7} L_{k, t-1}+\sum_{t=2}^{16} \delta_{t} Y_{t}+\epsilon_{k, t}
\end{array}
$$

where $\ln (r)$ is the natural logarithm of the rent, $\Delta$ foreign-born $_{k, t}$ is the change in the foreign-born population in location $k$ between $t-1$ and $t, \Delta$ Swedish-born $_{k, t}$ is the change in Swedish-born (internal) migration in location $k$ between $t-1$ and $t$, where Swedishborn rather than all internal migration is used to avoid double counting of foreign-born migrants. By population ${ }_{k, t-1}$ we denote the total population in location $k$ and time $t-1$, In is real income, $E m$ is employment, $T$ is a temperature average from $1961-1990, B$ is $\%$ of population with a bachelor's degree in 1984 per 10,000 inhabitants, $A$ is the percentage of the population aged 20-64 in 1984, NS is the new housing stock that becomes available in every year per 1,000 residents (a supply-side variable), $L$ is a dummy variable allowing me to account for the differing impacts of new Planning and Building Legislation that took effect in 2011 (another supply-side variable) where $1=2000-2010$ and $0=2011-2015$, $Y$ is years from 2000 to $2015 t=2, \ldots, 16$, and $\epsilon$ is the error term.

Following Saiz (2007), a shift-share instrumental variable approach will be taken, to control for potential endogeneity in the data. The approach makes use of migrant settlement patterns in the past, which tend to influence the settlement patterns of current migrants, but not be correlated with local economic conditions in the present, since they are based on exogenous push factors in the country or region of origin. The approach will take the following form:

$$
\overline{\overline{\Delta \text { foreign-born }_{k, t}}}=\overline{\overline{\Delta \text { foreign-born }_{\text {Sweden }, t, o}}} * \frac{\overline{\overline{\Delta \text { foreign-born }_{k, 1984}}}}{\overline{\overline{\Delta \text { foreign-born }_{\text {Sweden }, 1984}}}}
$$

$$
\begin{aligned}
\overline{\overline{\Delta \text { Swedish-born migration inflow }_{k, t}}}= & \overline{\overline{\Delta \text { Swedish-born migrations }_{\text {Sweden }, t} *}} \\
& \frac{\overline{\overline{\Delta \text { Swedish-born migration }_{\text {inflow }}, 1984}}}{\overline{\overline{\Delta \text { Swedish-born migrations }_{\text {Sweden }, 1984}}}}
\end{aligned}
$$

where $\Delta$ foreign-born $_{k, t}$ is the change in the foreign-born population in location $k$ between $t-1$ and $t$, and $\Delta$ Swedish-born migrations $_{k, t}$ is the change in Swedish-born (internal) migration in location $k$ between $t-1$ and $t$. Where the year listed is 1984, the variable refers to the share of the respective migrant population in that year.

The instrumental variable approach relies on settlement patterns in 1984, the earliest year for which data is available, to attempt to predict current settlement patterns among migrant groups. As such, it functions well as an instrument, since the past settlement patterns are correlated with current migration flows, owing to network and path dependency effects, but not with current rental values ${ }^{1}$. The approach assumes a wide variation in the composition and settlement patterns of different migrants over the studied period, which as noted in the earlier sections, is met in the case of Sweden.

Complete data is available from 2000 to 2015. As a robustness check, and to ensure that any migration effects being picked up are truly measuring the impact of the migration variable, the regression will first be run for 2000-2015, but then also run for 2000-2010 and 2011-2015, separately. This is because the deregulatory reform, detailed in Section 2 , should mean that migration is likely to have a stronger impact on rents after 2011, while impacts before 2011 should be smaller. A structural chow test will be used to test whether a structural break does indeed manifest in 2011.

\footnotetext{
${ }^{1}$ The instrument is also found to produce sufficiently sized Cragg-Donald and Kleibergen-Paap F statistics.
} 


\subsection{Regional Analysis}

Following the above regression, the municipalities will be classified based on their characteristics and ran in separate regressions. This should enable identification of potential differential effects between municipalities. This analysis will take the following form:

- Major Cities (24 municipalities)

- Urban Areas (25 municipalities)

This split is conducted owing to the descriptive statistics shown in Figure 2. As outlined in association with that diagram, the difference in the population size of major city and urban municipalities is substantial. Further, access to labour markets is much stronger in major city municipalities, as well as the ability to commute across municipalities for employment purposes (where as in smaller urban areas, this is much more condensed to the home municipality) (SCB 2019). As such, there are a number of fundamental differences between major cities and smaller urban areas that make these interesting for study separate to one another.

\subsection{Reason for Migration Analysis}

Finally, in one last regression, the migration-related variables will be broken down, based on reason for migration. This will also enable identification of differential impacts between migrants of different origins. This will take the following form:

- Labour migration (labour migrants, EU migrants, students)

- Family reunification migration

- Refugee migration

In this paper, I elect to distinguish between foreign-born and internal migration, owing to the differences seen in Figure 3 in terms of migration patterns, as well as the broad differences between different forms of foreign-born and internal migration. It is valuable to also break down foreign-born migration into the above groups, partly owing to the different experiences that these groups are likely to be faced with on the rental market, as outlined in Section 2.3. Since it is clear that migration patterns have varied broadly for different migration groups in major cities and urban areas, it is also interesting to note whether corresponding differences can be seen in the impacts of different forms of migration on rents.

\section{Results}

The results of the first regression are shown in Table 1. It shows a relatively weak, but significant impact of foreign-born migration on rents, significant at the $5 \%$ level, producing a coefficient of 0.249 in the IV regression. The fact that there is a significant, positive impact is relatively noteworthy, given that the largely regulated rent structure means the dependent variable is not able to vary freely, yet migration is still able to impact rental levels, even if on a diminished scale when compared to previous literature. This indicates that migration may be having a relatively large impact on rents in Sweden, compared to other factors. Nevertheless, other controlled variables such as income and new stock are also significant, indicating that it is not just migration alone that is driving up the cost of rent. Concurrently, the fact that Swedish-born internal migration is not significant at all is also noteworthy. These results are very interesting as they seem to indicate wide heterogeneity in the degree of impacts that different forms of migrants have on the rental market in Sweden. This could stem from relative interest in the rental market (as compared to other markets), as well as relative willingness and ability to spend. Swedish-born migrants, who generally have higher wealth than foreign-born migrants, may be relatively less interested in the rental market, while foreign-born migrants may be forced into this market to a higher degree. Further, preferences between the two groups may vary, as the latter group values the flexibility offered by the rental market more than the former group, resulting in a higher willingness to spend on rental accommodation. 
Table 1: The relationship between migration and rental levels

\begin{tabular}{|c|c|c|}
\hline & OLS & IV \\
\hline$\Delta$ Foreign-born $_{t} /$ Population $_{t-1}$ & $\begin{array}{c}0.236^{* *} \\
(0.107)\end{array}$ & $\begin{array}{c}0.249^{* *} \\
(0.109)\end{array}$ \\
\hline$\Delta$ Swedish-born $_{t} /$ Population $_{t-1}$ & $\begin{array}{c}0.090 \\
(0.071)\end{array}$ & $\begin{array}{c}0.102 \\
(0.110)\end{array}$ \\
\hline $\log$ income $_{t-1}$ & $\begin{array}{c}0.077^{* * *} \\
(0.028)\end{array}$ & $\begin{array}{c}0.094^{* * * *} \\
(0.031)\end{array}$ \\
\hline Employment $_{t-1}$ & $\begin{array}{c}0.041 \\
(0.037)\end{array}$ & $\begin{array}{c}0.044 \\
(0.038)\end{array}$ \\
\hline Log January temperature & $\begin{array}{c}0.000 \\
(0.000)\end{array}$ & $\begin{array}{c}-0.001 \\
(0.002)\end{array}$ \\
\hline New stock $t-1$ & $\begin{array}{c}0.021^{* *} \\
(0.009)\end{array}$ & $\begin{array}{c}0.022^{* *} \\
(0.009)\end{array}$ \\
\hline Legislation & $\begin{array}{c}-0.001 \\
(0.002)\end{array}$ & $\begin{array}{c}-0.005 \\
(0.007)\end{array}$ \\
\hline Year fixed effects & Yes & Yes \\
\hline Region fixed effects & Yes & Yes \\
\hline Observations & 880 & 880 \\
\hline R-Squared & 0.224 & 0.226 \\
\hline
\end{tabular}

Notes: $*$... significant on the $10 \%, * * \ldots 5 \%, * * * \ldots 1 \%$ level.

To verify whether the effect being picked up is truly that of migration, and not some other effect that is driving up house prices, I conduct separate regressions for the data from 2000-2010, and for data from 2011-2015 (as detailed in Section 3.1). The results are shown in Table 2.

Taken at face value, the results in Table 2 appear to indicate that the migration variable's impacts are indeed stronger between 2011-2015, while impacts seen between 2000-2010 are decidedly weaker (though not non-existent). Indeed, the foreign-born variable produces a coefficient of 0.254 , significant at the $1 \%$ level, while the impact between 2000 and 2010 is 0.180 , significant only at the $10 \%$ level. The income variable is also less significant between 2000-2010, while new stock is not significant at all. The differences in these results would suggest that a structural break is likely. The chow test confirms this - producing an f-value of 9.372, which is larger than the critical value of 1.5987. The p-value is also 0.000, further confirming the strength of these results. This would seem to indicate that the regressions are indeed capturing the impacts of foreign-born migration.

Having established the above, Table 3 allows me to study these trends in further detail, looking at these municipality characteristics. The regressions are only run from 2000-2015, in order to improve sample size. Also this table shows relatively few significant variables. Only foreign-born migration is significant in major cities, with a coefficient of 0.234 significant at the $10 \%$ level. This is consistent with Table 1 displayed earlier, and confirms that the theory regarding the generally stronger impact of foreign-born migration on the rental market, as well as generally, may hold true, at least in major cities. As such, it appears that foreign-born migration has a particularly strong impact on rents in major cities. In smaller urban areas, neither migration variable is significant, which could be explained by less pressure, in absolute terms, being placed on the rental market, which is less constrained owing to a larger amount of space and resources in smaller urban areas. Rental housing could perhaps also be less demanded owing to relative preferences toward other private housing cooperatives and owner-occupied housing, which is relatively more readily available than in major cities. However, the role of migrant preferences when looking for housing and the intersection between this and other relevant trends, such as economic opportunities and the role of small-town revival, could also be playing into the less significant impacts.

Adjusting policy to reflect the fact that foreign-born migration is likely to push up 
Table 2: The relationship between migration and rental levels over different time periods

\begin{tabular}{|c|c|c|c|c|c|c|}
\hline & \multicolumn{2}{|c|}{ 2000-2015 } & \multicolumn{2}{|c|}{ 2000-2010 } & \multicolumn{2}{|c|}{$2011-2015$} \\
\hline & OLS & IV & OLS & IV & OLS & IV \\
\hline$\Delta$ Foreign-born $_{t} /$ Population $_{t-1}$ & $\begin{array}{c}0.236 * * \\
(0.107)\end{array}$ & $\begin{array}{c}0.249 * * \\
(0.109)\end{array}$ & $\begin{array}{l}0.180^{*} \\
(0.104)\end{array}$ & $\begin{array}{l}0.195^{*} \\
(0.109)\end{array}$ & $\begin{array}{c}0.254^{* * *} * \\
(0.088)\end{array}$ & $\begin{array}{c}0.284^{* * * *} \\
(0.093)\end{array}$ \\
\hline$\Delta$ Swedish-born $_{t} /$ Population $_{t-1}$ & $\begin{array}{c}0.090 \\
(0.071)\end{array}$ & $\begin{array}{c}0.102 \\
(0.110)\end{array}$ & $\begin{array}{c}0.024 \\
(0.140)\end{array}$ & $\begin{array}{c}0.039 \\
(0.144)\end{array}$ & $\begin{array}{c}0.018 \\
(0.087)\end{array}$ & $\begin{array}{c}0.015 \\
(0.094)\end{array}$ \\
\hline $\log$ income $_{t-1}$ & $\begin{array}{c}0.077^{* * *} \\
(0.028)\end{array}$ & $\begin{array}{c}0.094^{* * *} \\
(0.031)\end{array}$ & $\begin{array}{l}0.056^{*} \\
(0.031)\end{array}$ & $\begin{array}{l}0.057^{*} \\
(0.031)\end{array}$ & $\begin{array}{c}0.162^{* * *} \\
(0.041)\end{array}$ & $\begin{array}{c}0.166^{* * * *} \\
(0.041)\end{array}$ \\
\hline Employment $_{t-1}$ & $\begin{array}{c}0.041 \\
(0.037)\end{array}$ & $\begin{array}{c}0.044 \\
(0.038)\end{array}$ & $\begin{array}{c}0.012 \\
(0.065)\end{array}$ & $\begin{array}{c}0.021 \\
(0.068)\end{array}$ & $\begin{array}{c}0.074 \\
(0.103)\end{array}$ & $\begin{array}{c}0.060 \\
(0.105)\end{array}$ \\
\hline Log January temperature & $\begin{array}{c}0.000 \\
(0.000)\end{array}$ & $\begin{array}{l}-0.001 \\
(0.002)\end{array}$ & $\begin{array}{c}0.002 \\
(0.004)\end{array}$ & $\begin{array}{c}0.002 \\
(0.004)\end{array}$ & $\begin{array}{c}0.000 \\
(0.001)\end{array}$ & $\begin{array}{c}0.000 \\
(0.001)\end{array}$ \\
\hline New stock ${ }_{t-1}$ & $\begin{array}{c}0.021^{* *} \\
(0.009)\end{array}$ & $\begin{array}{c}0.022^{* *} \\
(0.009)\end{array}$ & $\begin{array}{c}0.009 \\
(0.021)\end{array}$ & $\begin{array}{c}0.010 \\
(0.021)\end{array}$ & $\begin{array}{c}0.027^{* *} * \\
(0.010)\end{array}$ & $\begin{array}{c}0.029^{* *} \\
(0.011)\end{array}$ \\
\hline Legislation & $\begin{array}{l}-0.001 \\
(0.002)\end{array}$ & $\begin{array}{l}-0.005 \\
(0.007)\end{array}$ & & & & \\
\hline Year fixed effects & Yes & Yes & Yes & Yes & Yes & Yes \\
\hline Region fixed effects & Yes & Yes & Yes & Yes & Yes & Yes \\
\hline Observations & 880 & 880 & 605 & 605 & 275 & 275 \\
\hline R-Squared & 0.224 & 0.226 & 0.203 & 0.204 & 0.275 & 0.277 \\
\hline
\end{tabular}

Notes: $*$... significant on the $10 \%, * * \ldots 5 \%, * * * \ldots 1 \%$ level.

rental values more so than internal migration could be advisable in certain areas. Access to the rental market is vital, as it is often the first port of call for many more vulnerable groups or individuals in society, who lack access to the considerable funds required to access the private housing cooperate or owner-occupied housing market. Hence, targeted initiatives to avoid such vulnerable groups struggling to gain access to the rental market should perhaps be considered in response. This could include initiatives to alleviate pressure on the rental market, by e.g. encouraging more building, or instituting a targeted queue-jumping scheme. The results in Table 3 highlight that any policy adjustments targeted at the rental market should likely be focused to major cities, and particularly those which have received the largest relative influxes of foreign-born migrants.

Finally, to shine further light on any trends and potential requirement for policy adaptations, I look at the impacts of migration flows segmented by migrant background on rental levels in Table 4. In this table, I note generally weak or no impacts of migration flows on rents. The only significant impacts are produced by refugee migration, with 0.287 significant at the $10 \%$ level overall, and 0.374 significant at the $5 \%$ level in major cities. The lack of significance for other variables suggests broad heterogeneity in migrant impacts, perhaps owing to the system of rent regulation that is in place. It would, however, appear that refugee migrants are capable of creating a substantial shock to the rental market. This could be a result of a lack of competition stemming from other groups for this type of housing, with other forms of migrants instead favouring other forms of housing where possible.

It is also likely that the Swedish government's refugee placement policy is contributing to the impacts produced by refugees. The policy consists of mandating that all Swedish municipalities provide housing to a certain number of refugees (Wennström, Öner 2015), and this housing stock is likely to be taken from the rental market. Hence, although refugees may not directly be causing pressure on the rental market, indirect impacts could be resulting in refugees appearing to be the most impactful group on this market, as municipalities reserve rental housing for refugees, causing pressure on the rental market. A natural conclusion is to focus initiatives which alleviate pressure on the rental market to areas which have received an influx of refugees, particularly in major cities, where other migrants or natives may be pushed out of or struggle to gain access to the rental market. However, further initiatives could include looking into changing the allocation pattern of refugees and encouraging municipalities where the rental market has not been as 
Table 3: The relationship between migration and rental levels in different types of municipalities

\begin{tabular}{lcccc}
\hline & \multicolumn{2}{c}{ Major Cities } & \multicolumn{2}{c}{ Smaller Urban Areas } \\
& OLS & IV & OLS & IV \\
\hline$\Delta$ Foreign-born $_{t}$ Population $_{t-1}$ & $0.216^{*}$ & $0.234^{*}$ & 0.288 & 0.361 \\
& $(0.116)$ & $(0.121)$ & $(0.305)$ & $(0.333)$ \\
$\Delta$ Swedish-born $_{t}$ Population $_{t-1}$ & 0.144 & 0.121 & 0.151 & 0.114 \\
& $(0.123)$ & $(0.136)$ & $(0.199)$ & $(0.233)$ \\
Log income $t-1$ & 0.034 & 0.036 & -0.067 & -0.079 \\
& $(0.081)$ & $(0.099)$ & $(0.098)$ & $(0.145)$ \\
Employment $t-1$ & 0.032 & 0.023 & 0.072 & 0.082 \\
& $(0.037)$ & $(0.034)$ & $(0.079)$ & $(0.077)$ \\
Log January temperature & 0.001 & 0.002 & 0.001 & 0.002 \\
& $(0.002)$ & $(0.002)$ & $(0.001)$ & $(0.002)$ \\
Percentage with bachelor's degree & 0.023 & 0.026 & -0.081 & -0.099 \\
& $(0.024)$ & $(0.027)$ & $(0.071)$ & $(0.074)$ \\
Percentage working age $(1984)$ & -0.019 & -0.005 & 0.112 & 0.116 \\
& $(0.034)$ & $(0.021)$ & $(0.091)$ & $(0.097)$ \\
New Stock $t-1$ & 0.014 & 0.015 & 0.025 & 0.027 \\
& $(0.016)$ & $(0.017)$ & $(0.029)$ & $(0.029)$ \\
Legislation & -0.011 & -0.016 & -0.016 & -0.017 \\
& $(0.027)$ & $(0.029)$ & $(0.033)$ & $(0.034)$ \\
Year fixed effects & Yes & Yes & Yes & Yes \\
Observations & 384 & 384 & 400 & 400 \\
R-Squared & 0.191 & 0.192 & 0.280 & 0.282 \\
\hline
\end{tabular}

Notes: * ... significant on the $10 \%, * * \ldots 5 \%, * * * \ldots 1 \%$ level.

affected by migration to take in a larger share of refugees in future. This is a controversial initiative, though, and would have to be weighed against the wider societal impacts which such policy could have, e.g. through cost-benefit analysis.

Further, I note that the impacts of endogeneity appear to be fairly limited for the rental market. The only significant variables for the rental market appear to be affected by endogeneity to some degree - but the impacts are being very slightly underestimated, rather than overestimated, yet results do not appear to be overly affected by this.

\section{Conclusions}

In this paper I examine the impacts of foreign-born and internal migration on house prices on the rental market in Sweden. This extends the literature by analysing the effects of migration on a subset of the housing market that is highly unique, owing to its regulated nature, and has not been studied previously. Analysis is disaggregated on the regional level, and special emphasis is also placed on different forms of migration, including internal migration and a number of subsets of foreign-born migration. This allows one to highlight the impacts, or lack thereof, that a diverse range of migrant groups have on the rental market.

The results indicate a generally limited impact of migration on the rental market in Sweden - somewhat expected, given the regulated nature of the market. However, recent deregulation moves could be contributing to the fact that some significant impacts are found, for foreign-born migration, in particular. Indeed, disaggregation on the regional level, as well as by reason for migration, shows that foreign-born migration consisting of refugees in particular appears to be impactful in terms of housing rents in Sweden, primarily in major cities.

This is likely to be at least partly a result of the Swedish government's refugee placement policy, mandating that municipalities accept refugees regardless of the availability of housing. However, the rental market being most readily accessible to this group is also likely to play a role, pushing up prices for other groups wishing to access the market. This could have significant societal impact, as many vulnerable and less wealthy groups rely 
Table 4: Results by Reason for Migration

\begin{tabular}{|c|c|c|c|c|c|c|}
\hline & \multicolumn{2}{|c|}{ Overall } & \multicolumn{2}{|c|}{ Major Cities } & \multicolumn{2}{|c|}{ Smaller Urban Areas } \\
\hline & OLS & IV & OLS & IV & OLS & IV \\
\hline $\begin{array}{l}\Delta \text { Labour migration }_{t} / \\
\text { Population }_{t-1}\end{array}$ & $\begin{array}{c}0.188 \\
(0.511)\end{array}$ & $\begin{array}{c}0.286 \\
(0.736)\end{array}$ & $\begin{array}{c}1.388 \\
(1.743)\end{array}$ & $\begin{array}{c}1.144 \\
(1.905)\end{array}$ & $\begin{array}{c}0.618 \\
(1.344)\end{array}$ & $\begin{array}{c}0.733 \\
(1.905)\end{array}$ \\
\hline $\begin{array}{l}\Delta \text { Family reunification migration }_{t} / \\
\text { Population }_{t-1}\end{array}$ & $\begin{array}{c}0.300 \\
(0.508)\end{array}$ & $\begin{array}{c}0.219 \\
(0.671)\end{array}$ & $\begin{array}{c}0.188 \\
(0.344)\end{array}$ & $\begin{array}{l}0.195 \\
(0.355)\end{array}$ & $\begin{array}{c}0.700 \\
(1.390)\end{array}$ & $\begin{array}{c}0.411 \\
(1.739)\end{array}$ \\
\hline $\begin{array}{l}\Delta \text { Refugee migration }_{t} / \\
\quad \text { Population }_{t-1}\end{array}$ & $\begin{array}{l}0.246^{*} \\
(0.133)\end{array}$ & $\begin{array}{l}0.287^{*} \\
(0.155)\end{array}$ & $\begin{array}{c}0.388^{* *} \\
(0.166)\end{array}$ & $\begin{array}{c}0.374^{* *} \\
(0.167)\end{array}$ & $\begin{array}{c}0.301 \\
(0.361)\end{array}$ & $\begin{array}{c}0.236 \\
(0.415)\end{array}$ \\
\hline$\Delta$ Swedish-born $_{t} /$ Population $_{t-1}$ & $\begin{array}{l}0.087 \\
(0.088)\end{array}$ & $\begin{array}{l}0.099 \\
(0.101)\end{array}$ & $\begin{array}{l}0.131 \\
(0.104)\end{array}$ & $\begin{array}{l}0.167 \\
(0.133)\end{array}$ & $\begin{array}{c}0.181 \\
(0.139)\end{array}$ & $\begin{array}{l}0.194 \\
(0.166)\end{array}$ \\
\hline $\log _{\text {income }_{t-1}}$ & $\begin{array}{l}-0.066 \\
(0.040)\end{array}$ & $\begin{array}{l}-0.078 \\
(0.057)\end{array}$ & $\begin{array}{l}-0.114 \\
(0.076)\end{array}$ & $\begin{array}{l}-0.117 \\
(0.077)\end{array}$ & $\begin{array}{l}-0.158 \\
(0.071)\end{array}$ & $\begin{array}{l}-0.167 \\
(0.086)\end{array}$ \\
\hline Employment $_{t-1}$ & $\begin{array}{l}-0.041 \\
(0.082)\end{array}$ & $\begin{array}{l}-0.051 \\
(0.097)\end{array}$ & $\begin{array}{l}-0.011 \\
(0.073)\end{array}$ & $\begin{array}{l}-0.015 \\
(0.078)\end{array}$ & $\begin{array}{l}-0.107 \\
(0.148)\end{array}$ & $\begin{array}{l}-0.151 \\
(0.161)\end{array}$ \\
\hline Log January temperature & $\begin{array}{c}0.001 \\
(0.001)\end{array}$ & $\begin{array}{c}0.001 \\
(0.001)\end{array}$ & $\begin{array}{c}0.002 \\
(0.002)\end{array}$ & $\begin{array}{c}0.002 \\
(0.003)\end{array}$ & $\begin{array}{c}0.002 \\
(0.001)\end{array}$ & $\begin{array}{c}0.002 \\
(0.002)\end{array}$ \\
\hline Bachelor's degree $(\%, 1984)$ & $\begin{array}{c}0.016 \\
(0.022)\end{array}$ & $\begin{array}{c}0.009 \\
(0.017)\end{array}$ & $\begin{array}{c}0.021 \\
(0.026)\end{array}$ & $\begin{array}{c}0.025 \\
(0.028)\end{array}$ & $\begin{array}{l}-0.073 \\
(0.073)\end{array}$ & $\begin{array}{l}-0.087 \\
(0.075)\end{array}$ \\
\hline Working age $(\%, 1984)$ & $\begin{array}{l}-0.021 \\
(0.028)\end{array}$ & $\begin{array}{l}-0.028 \\
(0.035)\end{array}$ & $\begin{array}{l}-0.010 \\
(0.036)\end{array}$ & $\begin{array}{l}-0.015 \\
(0.039)\end{array}$ & $\begin{array}{c}0.123 \\
(0.093)\end{array}$ & $\begin{array}{c}0.137 \\
(0.099)\end{array}$ \\
\hline New stock $k_{t-1}$ & $\begin{array}{c}0.015 \\
(0.014)\end{array}$ & $\begin{array}{l}0.012 \\
(0.017)\end{array}$ & $\begin{array}{c}0.015 \\
(0.016)\end{array}$ & $\begin{array}{c}0.017 \\
(0.016)\end{array}$ & $\begin{array}{c}0.025 \\
(0.029)\end{array}$ & $\begin{array}{c}0.027 \\
(0.031)\end{array}$ \\
\hline Legislation & $\begin{array}{c}-0.001 \\
(0.002)\end{array}$ & $\begin{array}{l}-0.002 \\
(0.003)\end{array}$ & $\begin{array}{l}-0.003 \\
(0.003)\end{array}$ & $\begin{array}{l}-0.004 \\
(0.003)\end{array}$ & $\begin{array}{c}-0.002 \\
(0.004)\end{array}$ & $\begin{array}{l}-0.003 \\
(0.004)\end{array}$ \\
\hline Year fixed effects & Yes & Yes & Yes & Yes & Yes & Yes \\
\hline Observations & 880 & 880 & 384 & 384 & 400 & 400 \\
\hline R-Squared & 0.150 & 0.150 & 0.145 & 0.146 & 0.244 & 0.244 \\
\hline
\end{tabular}

Notes: * ... significant on the $10 \%, * * \ldots 5 \%, * * * \ldots 1 \%$ level.

on the rental market, unable to access other forms of housing markets. Hence, targeted initiatives to alleviate pressure on the rental market, particularly in major city areas which have been most affected by refugees and other migrants accessing the rental market, could be advisable. In addition, an adjustment to future refugee allocation policy to reflect the above trends and alleviate pressure further could be investigated. Further research could investigate these trends further, as well as look at the impacts of migration on less regulated markets, particularly in a disaggregated manner, as in this paper. 


\section{References}

Aitken A (2014) The effects of immigration on house prices and rents: Evidence from England and Wales. Royal Holloway, University of London. Mimeo

Bengtsson B (1994) Swedish rental policy - A complex superstructure with cracking foundations. Scandinavian Housing and Planning Research 11: 182-189. CrossRef.

Borjas G (2006) Native internal migration and the labor market impact of immigration. Journal of Human Resources XLI: 221-258. CrossRef.

Degen K, Fischer AM (2009) Immigration and Swiss house prices. CEPR Discussion Paper No. DP7583

Dustmann C, Frattini T (2014) The fiscal effects of immigration to the UK. The Economic Journal Feature Issue: F593-F643. CrossRef.

Eichholtz P, Lindenthal T (2014) Demographics, human capital, and the demand for housing. Journal of Housing Economics 26: 19-32. CrossRef.

Friedberg R, Hunt J (1995) The impact of immigrants on host country wages, employment and growth. The Journal of Economic Perspectives 9: 23-44. CrossRef.

Gerdes C, Wadensjö E (2010) Post-enlargement migration and labor market impact in Sweden. In: Kahanec M, Zimmermann K (eds), EU Labor Markets After PostEnlargement Migration. Springer, Berlin Heidelberg, 163-179. CrossRef.

Gonzalez L, Ortega F (2012) Immigration and housing booms: Evidence from Spain. Journal of Regional Science 53: 37-59. CrossRef.

Hammarstedt M, Palme M (2006) Intergenerational mobility, human capital transmission and the earnings of second-generation immigrants in Sweden. IZA Discussion Paper

Kerr S, Kerr W (2011) Economic impacts of immigration: A survey. NBER working paper. CrossRef.

Kürschner K (2017) Immigration and rental prices of residential housing: Evidence from the fall of the Berlin wall. Verein für Socialpolitik, annual conference 2017 (Vienna)

Latif E (2015) Immigration and housing rents in Canada: A panel data analysis. Economic Issues 20: 91-108

Lind H (2001) Rent regulation: A conceptual and comparative analysis. European Journal of Housing Policy 1: 41-57. CrossRef.

Migrationsverket (2018) Selected statistics. https://www.migrationsverket.se/Om-Migrationsverket/Statistik.html

Mussa A, Nwaogu UG, Pozo S (2017) Immigration and housing: A spatial econometric analysis. Journal of Housing Economics 35: 13-25. CrossRef.

Ottaviano GIP, Peri G (2005) Rethinking the gains from immigration: Theory and evidence from the U.S. NBER Working Paper. CrossRef.

SABO - Sveriges Allmännyttiga Bostadsföretag (2011) Allmännyttan. https://www.allmannyttan.se/historia/tidslinje/hyresratten-och-lagstiftningen/

Saiz A (2003) Room in the kitchen for the melting pot: Immigration and rental prices. The Review of Economics and Statistics 85: 502-521. CrossRef.

Saiz A (2007) Immigration and housing rents in American cities. Journal of Urban Economics 61: 345-371. CrossRef.

SCB - Statistics Sweden (2017) Selected statistics. http://www.scb.se/hitta-statistik/ 
SCB - Statistics Sweden (2018) Selected statistics. http://www.scb.se/hitta-statistik/

SCB - Statistics Sweden (2019) Selected statistics. http://www.scb.se/hitta-statistik/

Sharpe J (2015) Three essays on the economic impact of immigration. UKnowledge, University of Kentucky

Tumen S (2016) The economic impact of syrian refugees on host countries: Quasiexperimental evidence from Turkey. American Economic Review 106: 456-60. CrossRef.

Tyrcha A (2019) Why does the queue keep growing? The relationship between migration and rental housing queues in Sweden. Economics Bulletin 39: 1251-1258

Tyrcha A, Abreu M (2019) Migration diversity and housing prices - evidence from Sweden. https://ssrn.com/abstract $=3394234$

Wang X, Hui E, Sun J (2017) Population migration, urbanization and housing prices: Evidence from the cities in China. Habitat International 66: 49-56. CrossRef.

Wennström J, Öner (2015) Den geografiska spridningen av kommunplacerade flyktingar i Sverige. http://www.nationalekonomi.se/sites/default/files/NEFfiler/43-4-jwöö.pdf

World Bank (2019) Rental housing. http://documents.worldbank.org/curated/en/810681468339259949/pdf/Rental-Housing-lessons-from-international-experience-and-policiesfor-emerging-market.pdf

cc) (7) (8) (C) 2020 by the authors. Licensee: REGION - The Journal of ERSA, European Regional Science Association, Louvain-la-Neuve, Belgium. This article is distributed under the terms and conditions of the Creative Commons Attribution, Non-Commercial (CC BY NC) license (http://creativecommons.org/licenses/by-nc/4.0/). 